\title{
Ideas and perspectives: Emerging contours of a dynamic exogenous kerogen cycle
}

\author{
Thomas M. Blattmann ${ }^{1}$
}

${ }^{1}$ Biogeochemistry Research Center, Research Institute for Marine Resources Utilization, Japan Agency for Marine-Earth 5 Science and Technology (JAMSTEC), 2-15 Natsushima-cho, 237-0061 Yokosuka, Japan

Correspondence to: Thomas M. Blattmann (blattmannt@jamstec.go.jp)

\begin{abstract}
Growing evidence points to the dynamic role that kerogen is playing on Earth's surface in controlling atmospheric chemistry over geologic time. Although quantitative constraints on the weathering of kerogen remain loose, its changing weathering behavior modulated by the activity of glaciers suggest that this largest pool of reduced carbon on Earth may have played a key part in atmospheric $\mathrm{CO}_{2}$ variability across recent glacial-interglacial times and beyond. This work enunciates the possibility of kerogen oxidation as a major driver of atmospheric $\mathrm{CO}_{2}$ increase in the wake of glacial episodes. This hypothesis of centennial and millennial-timescale-relevance for this chemical weathering pathway is substantiated by several lines of independent evidence synthesized in this contribution including the timing of $\mathrm{CO}_{2}$ increase, $\mathrm{CO}_{2}$ isotopic composition $\left({ }^{13} \mathrm{C}\right.$ and ${ }^{14} \mathrm{C}$ ), seawater osmium record, kerogen oxidation kinetics, observations of kerogen reburial, and modeling results. The author hypothesizes that the deglaciation of kerogen-rich lithologies in western Canada contributed majorly to the characteristic deglacial increase in atmospheric $\mathrm{CO}_{2}$, which reached an inflection point $\leq 300$ years after the Laurentide Ice Sheet retreated into the kerogen-poor Canadian Shield. To quantitatively constrain the contribution of kerogen oxidation to $\mathrm{CO}_{2}$ rise at glacial terminations, systematic studies on $\mathrm{CO}_{2}$ fluxes emanating from the weathering of different lithologies, oxidation kinetics of kerogen along glacial chronosequences, and high-resolution temporal changes in the aerial extent of glacially exposed lithological units are needed.
\end{abstract}

\section{Introduction}

Over geologic timescales, atmospheric $\mathrm{CO}_{2}$ is controlled by the combined effects of chemical weathering of silicates and carbonates and the organic carbon cycle (Berner, 1990; Torres et al., 2014). Organic carbon in the form of kerogen comprises around 15 million $\mathrm{PgC}$, which encompasses over 99.9\% of reduced carbon present on Earth. Tectonic uplift and denudation subjects $150 \mathrm{PgC} / \mathrm{kyr}$ of kerogen to weathering on Earth's surface thereby facilitating entry of this geologically ancient carbon into the atmosphere and other surficial carbon pools standing in close communication (Hedges and Oades, 1997). Upon oxidation of kerogen, $\mathrm{O}_{2}$ is consumed and $\mathrm{CO}_{2}$ is released to the atmosphere. In reverse, biospheric organic carbon burial in marine sediments removes carbon from the Earth's surface thereby drawing down atmospheric $\mathrm{CO}_{2}$ and increasing $\mathrm{O}_{2}$ over geological timescales (Galy et al., 2008). Therefore, kerogen weathering and sedimentary organic matter burial in the ocean 
https://doi.org/10.5194/bg-2021-4

Preprint. Discussion started: 21 January 2021

(c) Author(s) 2021. CC BY 4.0 License.

(c) (i)

30 play compensational roles in governing atmospheric chemistry (Fig. 1) with kerogen oxidation considered important for atmospheric chemistry over million-year timescales (e.g., Petsch, 2014; Bolton et al., 2006).

However, the decay of kerogen on Earth's surface is incomplete, with physical erosion followed by riverine transport (Galy et al., 2015) and reburial in lacustrine and marine settings (Blattmann et al., 2018a; Blattmann et al., 2019b; Cui et al., 2016; Sparkes et al., 2020). The operation of this "simple cycle besides the more complicated common circulation of carbon",

35 enunciated by Sauramo (1938), begs the questions (i) what is the reburial efficiency of kerogen, (ii) what is the weathering efficiency of kerogen, (iii) what are their controlling factors, and (iv) what are the implications of them changing for atmospheric chemistry over geologic timescales? Here, this contribution hypothesizes a connection between kerogen oxidation and millennial/centennial-scale atmospheric $\mathrm{CO}_{2}$ increases at glacial terminations.

\section{Carbon isotopes and contradictions?}

40 The amount and carbon isotopic composition of atmospheric $\mathrm{CO}_{2}$ (Fig. 2) depend on (1) the terrestrial biospheric organic carbon pool, (2) the dissolved inorganic carbon pools residing in the surface and deep ocean, (3) exchanges between the atmosphere and the terrestrial biosphere and ocean, and (4) the export of organic matter and carbonate from the surface waters of the oceans (Sigman and Boyle, 2000). Across deglaciation, an increasingly voluminous terrestrial biosphere (Bird et al., 1994; Shackleton 1977; Shackleton et al., 1983) is inferred to have controlled an increase in the stable carbon isotopic composition of dissolved inorganic carbon in ocean waters. However, this line of reasoning is complicated by various carbon pools changing in size coeval to carbon isotope fractionation as carbon rotates between these (e.g., terrestrial biosphere, pedosphere; see also discussions in Zeng (2003, 2007)). Additionally, during times of highest $\mathrm{CO}_{2}$ increase in transitions from glacial to interglacial, negative stable carbon isotopic shifts in atmospheric $\mathrm{CO}_{2}$ have occurred (Fig. 3; Smith et al., 1999; Schmitt et al., 2012), which is a strong indicator of respired organic carbon acting as source directly to the atmosphere (Bauska et al., 2016). Additionally, the constraints imposed by radiocarbon clearly indicate there must have been a source of carbon to the atmosphere and ocean depleted or devoid of radiocarbon (Broecker and Clark 2010; Hain et al., 2014; Rafter et al., 2019; Zhao et al., 2018), thereby limiting potential contributions from a modern biospheric organic carbon source. Other studies have proposed that carbon sourced from dissolved inorganic carbon from the deep ocean was the predominant source for carbon to the atmosphere at glacial terminations (e.g., Hain et al., 2014). However, this hypothesis appears inconsistent with the negative

55 fluctuation observed in the ${ }^{13} \mathrm{C}$ fingerprint of atmospheric $\mathrm{CO}_{2}$ during this time and requires a complex overlay of processes to reconcile (Broecker and McGee, 2013). Terrestrial organic carbon comprises the sum of biospheric and surface exposed lithogenic (i.e., kerogen) forms of organic carbon, with both exhibiting similar ${ }^{13} \mathrm{C}$ signatures yet modern and dead ${ }^{14} \mathrm{C}$ signatures, respectively. As the author will argue, the ${ }^{13} \mathrm{C}$ and ${ }^{14} \mathrm{C}$ lines of evidence suggest the release of $\mathrm{CO}_{2}$ via kerogen oxidation to the atmosphere during deglaciation, contradicting (or complementing) the commonly held notions of a strictly increasing terrestrial organic carbon pool and major changes in ocean-atmosphere $\mathrm{CO}_{2}$ exchange. 
https://doi.org/10.5194/bg-2021-4

Preprint. Discussion started: 21 January 2021

(c) Author(s) 2021. CC BY 4.0 License.

(c) (i)

\section{Kerogen and glaciers}

Evidence accumulated in over a century of scientific studies supports that the reburial of kerogen has been more extensive during cold interludes in Earth history where glacial erosion and ice rafting dominated (Blattmann et al., 2018b). This general pattern of kerogen reburial is also observed spatially today with more efficient reburial in high latitude, glaciated than in low latitude sedimentary systems (Cui et al., 2016). This enhanced reburial efficiency strengthens the short-circuiting of the exogenous kerogen cycle keeping this ancient, reduced carbon locked away. However, under glaciofluvial conditions, the entry of kerogen-bound carbon into surficial carbon pools is promoted (Horan, 2018), with, glacial meltwater releasing dissolved organic matter from kerogen, which is readily degraded and consumed by microbes (Hood et al., 2009; Schillawski and Petsch, 2008; Sharp et al., 1999). Additionally, frost shattering together with the retreat of glaciers expose finely ground, high surface

70 area, reactive sediment, thereby accelerating oxidation and release of kerogen-bound carbon to the atmosphere (Fischer and Gaupp, 2005; Horan et al., 2017). The initially strong input of kerogen-derived $\mathrm{CO}_{2}$ would die down as the availability of glacially ground, reactive kerogen declines into the interglacial. Enhanced degradation of kerogen in the wake of glacial episodes is consistent with observations from areas of ongoing deglaciation (Horan et al., 2017). Analogously, glaciers as agents for accelerating chemical weathering by increased sediment yield and creation of high surface area reactive substrate

75 have also been invoked for silicate and carbonate minerals (Torres et al., 2017; Vance et al., 2009), with carbonate weathering constituting a source of $\mathrm{CO}_{2}$ to the atmosphere when sulfuric acid is involved (Torres et al., 2014). However, kerogen oxidation, owing to its faster weathering kinetics and direct conversion to $\mathrm{CO}_{2}$ leading to considerable losses in kerogen content over decadal timescales (Horan et al., 2017; Fischer et al., 2007), is a manifest process by which $\mathrm{CO}_{2}$ can directly be injected into the atmosphere and intricately linked to glacial-interglacial cyclicity (Fig. 2).

80 In the following, quantitative arguments are presented: Of the approximately $150 \mathrm{PgC} / \mathrm{kyr}$ of kerogen reaching the Earth's surface (Hedges and Oades, 1997), 43-25 PgC/kyr is currently exported by rivers to oceans (Galy et al., 2015; Copard et al., 2007), indicating that the modern-day reburial efficiency of this carbon lies in the ballpark of $30 \%$ (10-70\%). Normalized to global land area, the following average flux of carbon due to oxidation of kerogen to the atmosphere can be expected:

$0.72_{-0.41}^{+0.17} \mathrm{MgC} / \mathrm{km}^{2} \mathrm{yr}=\frac{150-43_{-25}^{+61} \mathrm{PgC} / \mathrm{kyr}}{149,000,000 \mathrm{~km}^{2}} \quad$ (Equation 1)

Reports of $\mathrm{CO}_{2}$ fluxes from kerogen are based on disparate study sites and methods (Table 1). From this, reported $\mathrm{CO}_{2}$ fluxes stemming from oxidation of rock disseminated forms of kerogen and across larger catchment areas under aerobic conditions span over two orders of magnitude ranging from 0.3 to $64 \mathrm{MgC} / \mathrm{km}^{2} / \mathrm{yr}$. The only quantities available for catchments of ongoing deglaciation stem from the Southern Alps of New Zealand, which are one to two orders of magnitude faster than the average Earth surface (ranging between $9-50 \mathrm{MgC} / \mathrm{km}^{2} / \mathrm{yr}$; Horan et al., 2017). Taking this flux range as a first order estimate, how would kerogen oxidation translate into changes in atmospheric $\mathrm{CO}_{2}$ concentration? In Zeng's (2003) modeling work postulating soil oxidation upon retreat of overriding glaciers, the effect of continuous inputs of organic matter-derived carbon 
https://doi.org/10.5194/bg-2021-4

Preprint. Discussion started: 21 January 2021

(c) Author(s) 2021. CC BY 4.0 License.

(c) (i)

directly to the atmosphere are calculated: $550 \mathrm{PgC}$ oxidized lead to $60 \mathrm{PgC}$ increase in atmospheric $\mathrm{CO}_{2}(30 \mathrm{ppm}$ increase).

Similarly, modeling by Simmons et al. (2016) also propose glacially overridden soil organic carbon oxidation upon deglaciation and calculate $600 \mathrm{PgC}$ release resulting in a 40-60 ppm increase in atmospheric $\mathrm{CO}_{2}$ (c.f., also Ciais et al. (2012) who calculate the deglacial oxidation of $700 \mathrm{PgC}$ of an "inert" terrestrial organic carbon pool). The idea of soil oxidation is mathematically analogous to kerogen oxidation in the hypothesis presented here. How much deglaciated terrain would therefore be needed to release 550-600 PgC of kerogen-derived carbon? Using Zeng's (2003) and Simmons et al.'s (2016) carbon release estimates and Horan et al.'s (2017) oxidation kinetics over a 6,000-year time window (timespan of greatest $\mathrm{CO}_{2}$ increase over the glacial-interglacial transition) and subtracting global average baseline kerogen oxidation:

Between 2 to 12 million $\mathrm{km}^{2}=\frac{\text { Between } 550 \text { to } 600 \mathrm{PgC}}{6000 y r *\left([\text { Between } 9 \text { to } 50]-0.72_{-0.41}^{+0.17}\right) \mathrm{MgC} / \mathrm{km}^{2} \mathrm{yr}}$

105 In the most conservative estimate, 12 million $\mathrm{km}^{2}$ of deglaciated terrain containing sedimentary and metasedimentary rocks and their debris (glacial flour accumulated over millennia of glaciation) would cover the source. In comparison, Canada covers approximately 10 million $\mathrm{km}^{2}$, which was mostly covered by the Laurentide Ice Sheet during the Last Glacial Maximum. With this, a plausible scenario for releasing kerogen-derived $\mathrm{CO}_{2}$ to the atmosphere that could account for a 30-60 ppm rise during the glacial-interglacial transition encompassing an area equal to or less than the terrestrial extent of the Laurentide Ice Sheet

110 is identified. Similar to the oxidation fluxes reported from deglaciating catchments (Horan et al., 2017) are those reported for the in-situ weathering of massive outcrop formations of marls and shales (e.g., Soulet et al., 2018; Littke et al., 1991; see Table 1). Kerogen oxidation fluxes appear higher for catchments showing larger glacial coverage (Horan et al., 2017) suggesting that the relative contribution of freshly exposed and ground bedrock is highest for these areas and that kerogen oxidation fluxes progress over the course of deglaciation. The $\mathrm{CO}_{2}$ flux emanating from kerogen oxidation in soils formed from glacial till 115 (Keller and Bacon, 1998) suggests that oxidation fluxes greater by an order of magnitude than the global average can be sustained for millennia past deglaciation. However, a systematic chronosequence understanding is currently lacking that allows conclusions to be drawn as a variety of factors (e.g., lithology, initial kerogen content, grain size) exert control over kerogen oxidation (c.f., Fischer and Gaupp, 2005; Bolton et al., 2006). The bedrock and river sediments of the Southern Alps are relatively lean in kerogen (Copard et al., 2007; Horan et al., 2017). Therefore, for catchments exhibiting glacially ground

120 kerogen-rich lithologies, larger oxidation fluxes can be expected from such deglaciated landscapes (see next section). Long-term accelerated decline in the radiocarbon concentration of atmospheric $\mathrm{CO}_{2}$ parallel to an overall increase in $\mathrm{CO}_{2}$ amount occurred since the Last Glacial Maximum (Reimer et al., 2013; Roth and Joos, 2013). Consistent with such a dilutional process, kerogen oxidation releases radiocarbon-dead $\mathrm{CO}_{2}$ to the atmosphere. During the time period of greatest $\mathrm{CO}_{2}$ increase from 17.5 until $11.5 \mathrm{kyr}$ before present, the rate of decline in the concentration of ${ }^{14} \mathrm{C}$ in atmospheric $\mathrm{CO}_{2}$ is greatest and 125 averages about $35 \% / \mathrm{kyr}$ (Fig. 3; c.f., Broecker and Barker (2007)). With the release of $500 \mathrm{PgC}$ (radiocarbon-dead) to the atmosphere over deglaciation, a drop in 100 to $200 \% \Delta^{14} \mathrm{C}$ of atmospheric $\mathrm{CO}_{2}$ can be expected (see calculations by Zeng, 
https://doi.org/10.5194/bg-2021-4

Preprint. Discussion started: 21 January 2021

(c) Author(s) 2021. CC BY 4.0 License.

(c) (i)

2007; c.f., Sarntheim et al. (2013) who propose a comparable release yet argue for an oceanic mechanism). Kerogen oxidation would also release isotopically light carbon to the atmosphere, which is also consistent with the atmospheric record (Fig. 3; Bauska et al., 2016). Finally, driven by orbital forcing (Hays et al., 1976), the response in atmospheric $\mathrm{CO}_{2}$ faithfully echoing increasing global temperatures and diminishing glaciated terrain (Sigman and Boyle, 2000; Stips et al., 2016) goes hand in hand with continuous aerial exposure and enhanced oxidation of finely ground, reactive kerogen (Fig. 2).

\section{A Canadian tale. And what about microbes?}

Controlled to a first order by lithology, kerogen exposed on Earth's surface is distributed unevenly, with kerogen-rich surface lithologies extending along much of western Canada (see Fig. 2 in Copard et al., 2007). These areas experienced dramatic

135 deglaciation across the 17.5-11.5 ka timeframe (Fig. 4; Dyke, 2004; Dalton et al., 2020). In addition to the widespread occurrence and high abundance of rock disseminated forms of kerogen, there are also notable surficial occurrences of hydrocarbon-rich lithologies including coal and oil sands within the deglaciated terrains of western Canada. Within Alberta province, Andriashek and Pawlowicz (2002) report the widespread occurrence of reworked shale and bitumen in Quaternary till stemming from Cretaceous shales the oil sands, with unoxidized and oxidized forms present, and the latter enhanced by

140 aerial exposure along paleosurfaces. Today, bituminous erratic boulders are found strewn around the region across tens of thousands of square kilometers (Rutherford, 1928; Andriashek, 2018). As Andriashek (2018) points out, Rutherford (1928) states: "There are perhaps many more occurrences of bituminous sand within the glacial deposits of Alberta, but since they weather comparatively readily and become covered with soil, they are not likely to be detected unless by accident, ...". This observation of rapid weathering of bitumen indicates that today's occurrences in glacial tills represent the tip of the iceberg of

145 what once was present. $\mathrm{CO}_{2}$ respiration from bituminous materials based on laboratory incubations reveal fluxes that are markedly higher in comparison to oxidation of rock disseminated forms of kerogen (see Table 1). Chang and Berner (1998, 1999) report subaquatic bituminous coal oxidation (calculated $>300 \mathrm{MgC} / \mathrm{km}^{2} / \mathrm{yr}$ ) releasing $\mathrm{CO}_{2}$ greater by $1-2$ orders of magnitude than values reported from oxidation of rock disseminated kerogen and 3 orders of magnitude greater than for the average Earth's surface. Microbes likely play key roles in assimilating and releasing this ancient organic carbon as $\mathrm{CO}_{2}$ to the atmosphere (ZoBell, 1946; Hemingway et al., 2018) with microbial communities on the surface colonizing oil sand-derived bitumen under both summer and winter conditions (Wyndham and Costerton, 1981; Wong et al., 2015). Biodegradation is accelerated during summer months where subaerially exposed outcrops of oil sands reach $60^{\circ} \mathrm{C}$ (Wong et al., 2015). Microbial degradation experiments of bitumen (Ait-Langomazino et al., 1991) reveal an even greater $\mathrm{CO}_{2}$ release when extrapolated to natural systems (e.g., oil sands, see Table 1) exceeding $18 \mathrm{MgC} / \mathrm{km}^{2} /$ day, over one hundred times greater than the highest $\mathrm{CO}_{2}$

155 flux released by rock disseminated kerogen oxidation. Other laboratory-based studies (e.g., Uribe-Alvarez et al., 2011) studying oxidative decay of hydrocarbon fractions also suggest similarly astronomical fluxes when scaled to natural systems, which however only monitor over time periods of weeks. Such observations likely overestimate long-term natural fluxes over multiple years and decades, while the fluxes by Chang and Berner $(1998,1999)$ likely represent an underestimation due to 
https://doi.org/10.5194/bg-2021-4

Preprint. Discussion started: 21 January 2021

(c) Author(s) 2021. CC BY 4.0 License.

(c) (i)

sample storage for several years prior to analysis and the absence of microbial activity under their experimental conditions. Additionally, comparable quantities of kerogen-derived $\mathrm{CO}_{2}$ can also release under anaerobic conditions, which may become relevant under warming glaciers (e.g., Bertassoli Jr. et al., 2016; Rogieri Pelissari et al., 2021; see also Sharp et al., 1999; Sharp and Tranter, 2017). Therefore, it is unclear how much such potential super carbon source terrains supply a disproportionate quantity of radiocarbon dead $\mathrm{CO}_{2}$ to the atmosphere over glacial-interglacial transitions.

By $11.5 \mathrm{ka}$ before present, the pronounced rise in atmospheric $\mathrm{CO}_{2}$ had subsided. By this time, the Laurentide Ice Sheet retreated beyond the easternmost reaches of the Western Canadian Sedimentary Basin and was now exposing bedrock from the relatively kerogen-poor, highly metamorphosed Canadian Shield (Fig. 4; Dalton et al., 2020). The timing of the inflection point in the rise of $\mathrm{CO}_{2}$ occurs $\leq 300$ after the entire western edge of the Laurentide Ice Sheet moves fully into the Canadian Shield suggesting abating decay of kerogen and relaxation of the landscape. By this time, the rate of soil organic carbon sequestration in these paraglacial landscapes begins to pick up substantially (Harden et al., 1992). Lithologies of the Fennoscandian Shield and most of its adjacent landmasses (deglaciated eastern and southern sectors of the Fennoscandian Ice Shield; see Stroeven et al., 2016 and Copard et al., 2007) also contain relatively low kerogen contents, therefore limiting the contributions of atmospheric $\mathrm{CO}_{2}$ rise in the wake of Fennoscandian Ice Sheet retreat. Glacially ground graphite shed from these highly metamorphosed rocks behaves chemically recalcitrant and is mostly redeposited (Sauramo, 1938; Sparkes et al., 2020).

175 In the bigger picture, during Earth's recent glacial episodes, the Laurentide Ice Sheet represents the aerially most extensive part of the cryosphere that waxed and waned across the continents (Batchelor et al., 2019) and in conjunction with its lithological underpinning (Copard et al., 2007) likely played the largest role in releasing kerogen-derived $\mathrm{CO}_{2}$ to the atmosphere upon glacial retreat. However, estimates on $\mathrm{CO}_{2}$ fluxes emanating from bedrock show a wide range (Table 1) and considerable uncertainty resides in our current state of knowledge: Dedicated biogeochemical weathering studies are lacking

180 which provide carbon fluxes emanating from bedrock-derived kerogen under relevant environmental conditions and timescales. Chronosequence studies of kerogen oxidation rates in deglaciated terrains are needed to provide constraints on time-integrated $\mathrm{CO}_{2}$ release to the atmosphere. Such information in conjunction with high-resolution spatiotemporal changes in land ice extent together with lithology of bedrock and glacial till can theoretically quantitatively disentangle the contribution of kerogen-derived $\mathrm{CO}_{2}$ to the atmosphere during glacial-interglacial transitions.

\section{Tackling geologic deep time}

While modern day kerogen weathering and reburial efficiencies are only loosely constrained, even less is known about how they varied back in geologic time. Overarching controls on these processes include the mode of erosion and transport ranging from glacial to glaciofluvial to fluvial, remineralization intensity, controlled by continental margin type and geomorphology, and the intrinsic reactivity of the kerogen present locally (Blair and Aller, 2012; Blattmann et al., 2018b). Also important is

190 bedrock lithology and regolith composition which have been hypothesized to exert feedback on temporal patterns of glacial- 
https://doi.org/10.5194/bg-2021-4

Preprint. Discussion started: 21 January 2021

(c) Author(s) 2021. CC BY 4.0 License.

(c) (i)

interglacial cyclicity (e.g., Roy et al., 2004; Zeng, 2007). For the Paleocene-Eocene Thermal Maximum, an extreme greenhouse episode, evidence increasingly points towards enhanced remineralization and leaching of kerogen (Boucsein and Stein, 2009; Lyons et al., 2019), possibly enhanced by the activity of microbes (Hemingway et al., 2018; Petsch et al., 2001), thereby increasing the flux of carbon entering actively circulating pools on Earth's surface. Across Earth's history over $10^{9}$ year timescales, kerogen reburial efficiency presumably varied as a function of atmospheric $\mathrm{O}_{2}$ content, with lower $\mathrm{O}_{2}$ contents tied to higher reburial efficiency (Daines et al., 2017). Kerogen is surmised to have acted as a major source of carbon to the atmosphere and as an "antioxidant" during the early rise of atmospheric $\mathrm{O}_{2}$ (Daines et al., 2017; Kump et al., 2011). Across multiple glacial-interglacial cycles, enhanced kerogen oxidation would also be consistent with declining atmospheric $\mathrm{O}_{2}$ over $10^{6} \mathrm{yr}$ timescales (Stolper et al., 2016).

In order to understand atmospheric chemistry through geologic time, in addition to comprehensively budgeting the effect of mineral chemical weathering (Blattmann et al., 2019a; Horan et al., 2019; Hilton et al., 2014), changing reburial efficiency of sedimentary kerogen needs to be evaluated. Direct quantification of kerogen found reburied in sediments is often associated with considerable uncertainty owing to uncertainties in organic matter source apportionment (e.g., Lin et al., 2020; Blattmann et al., 2019b) and geospatial variability (e.g., Blattmann et al., 2018a; Cui et al., 2016). While radiocarbon was paramount for establishing the importance of and quantifying kerogen reburial in the Recent (Blattmann et al., 2018b), the utility of radiocarbon quickly diminishes for strata preceding the Last Glacial Maximum owing to its radioactive decay. However, associated with kerogen are a promising suite of trace elements and their respective isotope signatures including, among others, rhenium (Hilton et al., 2014; Horan et al., 2017), osmium (Georg et al., 2013; Ravizza and Esser, 1993), and iodine (Moran et al., 1998), that can be exploited to trace sedimentary kerogen and its degradation. In the case of osmium, seawater records reveal isotopic shifts at the beginning of interglacials attributable to the oxidation of kerogen (Georg et al., 2013; compare discussions in Peucker-Ehrenbrink and Ravizza, 2020), consistent with the presented hypothesis. More research constraining the exogenous kerogen cycle by quantification of reburied kerogen inputs (e.g., iodine isotopes, organic petrology) and kerogen oxidation recorded by chemical weathering proxies (e.g., osmium isotopes) is needed to put the presented hypothesis to the test.

\section{Synthesis and outlook}

In a nutshell, the presented hypothesis proposes the following: Less than 300 years after the Laurentide Ice Sheet retreated east past the easternmost edges of the kerogen-rich Western Canadian Sedimentary Basin, atmospheric $\mathrm{CO}_{2}$ levels stabilized and its rate of ${ }^{14} \mathrm{C}$ decline subsided (Figs. 3 and 4). This inflection point is mirrored in the surficial lithologies of the Canadian Shield, which exposed comparatively minor amounts of reactive kerogen to the elements upon further deglaciation. Within the context of the presented hypothesis, the coincidence of global trends in atmospheric chemistry with spatiotemporal patterns of freshly exposed deglaciated terrain impregnated with oxidizable and biodegradable kerogen and bituminous materials suggest that a burst(s) of respired $\mathrm{CO}_{2}$ contributed to the characteristic deglacial rebound in atmospheric $\mathrm{CO}_{2}$. As soon as glacially 
https://doi.org/10.5194/bg-2021-4

Preprint. Discussion started: 21 January 2021

(c) Author(s) 2021. CC BY 4.0 License.

(c) (i)

ground shales and bituminous materials either exhausted their labile kerogen content and/or became buried by soil and vegetation taking hold of the deglaciated landscape, classically considered processes (land-ocean exchange, biospheric uptake,

etc.) reassumed dominant control on fluctuations of atmospheric chemistry. As a corollary of this hypothesis: $\mathrm{CO}_{2}$ rise within the envelope of glacial-interglacial cyclicity would primarily have responded as a slave to orbitally controlled glacial retreat across kerogen impregnated landscapes as a result of global temperature increase. $\mathrm{CO}_{2}$ rise may therefore lead or lag global temperature depending on the spatiotemporal patterns of glacial retreat exposing glacially ground, kerogen-impregnated or even bituminous parent material.

Various mechanisms for explaining $\mathrm{CO}_{2}$ increases at glacial interglacial transitions have been proposed (e.g., Martin, 1990; Broecker and Peng, 1993; Rapp, 2019). However, as a cogwheel operating under manifold feedbacks in the greater Earth system (Sigman and Boyle, 2000), continuous glacial retreat and oxidation of finely ground kerogen provides a hypothesis consistent with a $\mathrm{CO}_{2}$ increase in the wake of glacial episodes. This dilution of radiocarbon-dead $\mathrm{CO}_{2}$ in the atmosphere may well have been complemented by other terrestrial sources such as subglacial paleosol oxidation (Zeng, 2007; Simmons et al., 2016), permafrost-bound organic carbon oxidation (Tesi et al., 2016; Winterfeld et al., 2018; Köhler et al., 2014; Ciais et al., 2012), and by (time-delayed) volcanic emissions due to unloading of the lithosphere (Roth and Joos, 2012). In addition to studies of weathering in glacial forefields and source-to-sink tracing of sedimentary kerogen, several lines of geochemical evidence including atmospheric carbon isotopic composition $\left({ }^{13} \mathrm{C}\right.$ and $\left.{ }^{14} \mathrm{C}\right)$, which have thus far received contorted, partial explanations (Broecker and Clark, 2010; Schmitt et al., 2012; Broecker and McGee, 2013), glacial-interglacial changes in ${ }^{14} \mathrm{C}$ of dissolved inorganic carbon in seawater (Rafter et al., 2019, c.f., discussions therein), seawater osmium isotope changes, and long-term atmospheric $\mathrm{O}_{2}$ content, conceptually go hand-in-hand with an opening of the exogenous kerogen cycle modulated by glacial activity. While geomagnetic variability and ocean ventilation together struggle to fully explain observed changes in atmospheric radiocarbon (Broecker and Barker, 2007; Cheng et al., 2018), the dilution of atmospheric $\mathrm{CO}_{2}$ by accelerated ancient terrestrial organic carbon oxidation at glacial terminations, in conjunction with other mechanisms including atmosphere-ocean gas exchange (e.g., Sigman et al., 2010; Marcott et al., 2014; Menviel et al., 2018; Martin, 1990; Sarntheim et al., 2013) appears as a simple and plausible explanation. In addition to kerogen oxidation at glacial terminations, the presented hypothesis carries other important implications, including the closure of the exogenous kerogen cycle during glacial periods (Fig. 2) potentially contributing to relatively high atmospheric ${ }^{14} \mathrm{C}$ signatures, a problem highlighted by Dinauer et al. (2020), as a reduced ${ }^{14} \mathrm{C}$-free $\mathrm{CO}_{2}$ flux would reduce the dilution of the atmosphere's cosmogenic ${ }^{14} \mathrm{C}$. Overall, increased reburial efficiency of kerogen can account for several tens of $\mathrm{PgC}$ over millennial timescales entirely bypassing actively circulating carbon pools on Earth's surface (Fig. 1). In contrast, increased oxidation efficiency of kerogen in the wake of glacial episodes that have built up stores of finely ground reactive substrate and expose fresh weathering profiles can account for several hundreds of $\mathrm{PgC}$ over millennial timescales released into actively circulating pools. Owing to increased bedrock exhumation over the Ice Ages (Herman et al., 2013; Herman et al., 2015) the dynamism of the exogenous kerogen cycle may have been intensified, with greater fluxes of detrital kerogen reburied in ocean sediments during glacial episodes and enhanced supplies of ground kerogen exposed to the elements in their wake. 
https://doi.org/10.5194/bg-2021-4

Preprint. Discussion started: 21 January 2021

(C) Author(s) 2021. CC BY 4.0 License.

(c) (i)

While basic controls on kerogen reburial efficiency have emerged, its quantitative impact on atmospheric chemistry through geologic time remains conjectural. Mathematically analogous modeling results (Zeng, 2003; Simmons et al., 2016) suggest that kerogen oxidation could account for 30-60 ppm rise in atmospheric $\mathrm{CO}_{2}$ over the course of the last deglaciation. However, there is a lack of data on kerogen weathering to provide sufficient quantitative constraint for testing this hypothesis. To work towards such a test, investigating kinetics of kerogen oxidation along glacial chronosequences with contrasting lithologies would provide numerical input for Earth system models. Such information in conjunction with spatiotemporal changes in land ice extent (e.g., Dalton et al., 2020; Stroeven et al., 2016) integrating over areal changes of glacially exposed lithological units (c.f., Copard et al., 2007) would constrain the quantitative impact of the exogenous kerogen cycle on atmospheric chemistry over glacial-interglacial cycles. Additionally, the role of super carbon source terrains (e.g., surficial oil sands and coal) deserve special attention as biogeochemical weathering and associated $\mathrm{CO}_{2}$ fluxes emanating from such areas conceivably contribute disproportionately, particularly upon deglaciation. Overall, the spatiotemporal deglaciation of contrasting source terrains across North America with the coeval progression of atmospheric chemistry provide strong incentive to explore the potential role of the exogenous kerogen cycle on glacial-interglacial patterns. From a greenhouse perspective, further study of pivotal episodes such as the Paleocene-Eocene Thermal Maximum under this lens may provide an outlook for geological processes relevant today. In the context of our warming world, once critical thresholds are breached (Steffen et al., 2018), enhanced opening of the exogenous kerogen cycle may entrain the Earth system onto a new trajectory influencing the carbon cycle and climate for millennia to come.

\section{Acknowledgments}

275 This work greatly benefitted from the input of two anonymous reviewers. The author is thankful for discussions with Timothy Eglinton, Dominik Letsch, Maarten Lupker, Jesper Suhrhoff, Valier Galy, and Robert Hilton. This work was supported by funding from JAMSTEC.

\section{Competing interests}

The author declares that he has no conflict of interest.

\section{Author contributions}

TMB conceived of and wrote this contribution. 
https://doi.org/10.5194/bg-2021-4

Preprint. Discussion started: 21 January 2021

(c) Author(s) 2021. CC BY 4.0 License.

(c) (i)

\section{References}

Ait-Langomazino, N., Sellier, R., Jouquet, G. and Trescinski, M.: Microbial degradation of bitumen, Experientia, 47, 533-539, 1991.

285 Andriashek, L. D.: On the origin of oil sand and related bedrock erratics in glacial sediments of central Alberta; Alberta Energy Regulator / Alberta Geological Survey, AER/AGS Open File Report 2018-13, 42 p, 2018.

Andriashek, L. D. and Pawlowicz, J. G.: Observations of naturally occurring hydrocarbons (bitumen) in Quaternary sediments, Athabasca Oil Sands area and areas west, Alberta; Alberta Energy and Utilities Board, EUB/AGS Geo-Note 2002-01, 27 p, 2002.

Batchelor, C. L., Margold, M., Krapp, M., Murton, D. K., Dalton, A. S., Gibbard, P. L., Stokes, C. R., Murton, J. B. and Manica, A.: The configuration of Northern Hemisphere ice sheets through the Quaternary, Nat. Commun., 10, 3713, 2019.

Bauska T. K., Baggenstos D., Brook E. J., Mix A. C., Marcott S. A., Petrenko V. V., Schaefer H., Severinghaus J. P. and Lee J. E.: Carbon isotopes characterize rapid changes in atmospheric carbon dioxide during the last deglaciation. Proc. Natl. Acad. Sci. U.S.A., 113, 3465-3470, 2016.

295 Berner R. A.: Atmospheric carbon dioxide levels over Phanerozoic time. Science, 249, 1382-1386, 1990.

Bertassoli Jr., D. J., Sawakuchi, H. O., Almeida, N. S., Castanheira, B., Alem, V. A. T., Camargo, M. G. P., Krusche, A. V., Brochsztain, S. and Sawakuchi, A. O.: Biogenic methane and carbon dioxide generation in organic-rich shales from southeastern Brazil, Int. J. Coal Geol., 162, 1-13, 2016.

Bird, M. I., Lloyd, J. and Farquhar, G. D.: Terrestrial carbon storage at the LGM. Nature 371, 566-566, 1994.

Blair N. E. and Aller R. C.: The fate of terrestrial organic carbon in the marine environment. Annu. Rev. Mar. Sci., 4, 401423, 2012.

Blattmann T. M., Zhang Y., Zhao Y., Wen K., Lin S., Li J., Wacker L., Haghipour N., Plötze M., Liu Z. and Eglinton T. I.: Contrasting fates of petrogenic and biospheric carbon in the South China Sea. Geophys. Res. Lett., 45, 9077-9086, $2018 \mathrm{a}$.

Blattmann T. M., Letsch D. and Eglinton T. I.: On the geological and scientific legacy of petrogenic organic carbon. Am. J. 305 Sci., 318, 861-881, 2018b.

Blattmann T. M., Wang S. L., Lupker M., Märki L., Haghipour N., Wacker L., Chung L. H., Bernasconi S. M., Plötze M. and Eglinton T. I.: Sulphuric acid-mediated weathering on Taiwan buffers geological atmospheric carbon sinks. Sci. Rep., 9, 2945, 2019a.

Blattmann T. M., Wessels M., McIntyre C. P. and Eglinton T. I.: Petrogenic organic carbon retention in terrestrial basins: A case study from perialpine Lake Constance. Chem. Geol., 503, 52-60, $2019 \mathrm{~b}$.

Bolton E. W., Berner R. A. and Petsch S. T.: The weathering of sedimentary organic matter as a control on atmospheric $\mathrm{O}_{2}$ : II. Theoretical modelling. Am. J. Sci., 306, 575-615, 2006.

Boucsein B. and Stein R.: Black shale formation in the late Paleocene/early Eocene Arctic Ocean and paleoenvironmental conditions: New results from a detailed organic petrological study. Mar. Petroleum Geol., 26, 416-426, 2009. 
https://doi.org/10.5194/bg-2021-4

Preprint. Discussion started: 21 January 2021

(c) Author(s) 2021. CC BY 4.0 License.

\section{(c) (1)}

315 Broecker W. and Clark E.: Search for a glacial-age ${ }^{14}$ C-depleted ocean reservoir. Geophys. Res. Lett., 37, 2010.

Broecker, W. S. and McGee, D.: The ${ }^{13} \mathrm{C}$ record for atmospheric $\mathrm{CO}_{2}$ : What is it trying to tell us? Earth Planet. Sci. Lett., 368, 175-182, 2013.

Broecker, W. and Barker, S.: A 190\% drop in atmosphere's $\Delta{ }^{14} \mathrm{C}$ during the "Mystery Interval" (17.5 to $\left.14.5 \mathrm{kyr}\right)$. Earth Planet. Sci. Lett., 256, 90-99, 2017.

320 Broecker, W. S. and Peng, T. H.: What caused the glacial to interglacial $\mathrm{CO}_{2}$ change?, in: Heimann, M. The Global Carbon Cycle. Springer Berlin Heidelberg, Berlin, Heidelberg, pp. 95-115, 1993.

Chang, S. and Berner, R. A.: Humic substance formation via the oxidative weathering of coal, Environ. Sci. Technol., 32, 2883-2886, 1998.

Chang, S. and Berner, R. A.: Coal weathering and the geochemical carbon cycle, Geochim. Cosmochim. Acta, 63, 3301-3310, 1999.

Cheng, H., Edwards, R. L., Southon, J., Matsumoto, K., Feinberg, J. M., Sinha, A., Zhou, W., Li, H., Li, X., Xu, Y., Chen, S., Tan, M., Wang, Q., Wang, Y. and Ning, Y.: Atmospheric ${ }^{14} \mathrm{C} /{ }^{12} \mathrm{C}$ changes during the last glacial period from Hulu Cave. Science, 362, 1293-1297, 2018.

Ciais, P., Tagliabue, A., Cuntz, M., Bopp, L., Scholze, M., Hoffmann, G., Lourantou, A., Harrison, S. P., Prentice, I. C., Kelley,

D. I., Koven, C. and Piao, S. L.: Large inert carbon pool in the terrestrial biosphere during the Last Glacial Maximum, Nat. Geosci., 5, 74-79, 2012.

Clark, M. G., Drewitt, G. B. and Carey, S. K.: Energy and carbon fluxes from an oil sands pit lake, Sci. Total Environ., 752, 141966, 2021.

Copard, Y., Amiotte-Suchet, P. and Di-Giovanni, C.: Storage and release of fossil organic carbon related to weathering of 335 sedimentary rocks, Earth Planet. Sci. Lett., 258, 345-357, 2007.

Cui, X., Bianchi, T. S., Jaeger, J. M. and Smith, R. W.: Biospheric and petrogenic organic carbon flux along southeast Alaska, Earth Planet. Sci. Lett., 452, 238-246, 2016.

Daines S. J., Mills B. J. W. and Lenton T. M.: Atmospheric oxygen regulation at low Proterozoic levels by incomplete oxidative weathering of sedimentary organic carbon. Nat. Commun., 8, 14379, 2017.

340 Dalton, A. S., Margold, M., Stokes, C. R., Tarasov, L., Dyke, A. S., Adams, R. S., Allard, S., Arends, H. E., Atkinson, N., Attig, J. W., Barnett, P. J., Barnett, R. L., Batterson, M., Bernatchez, P., Borns, H. W., Breckenridge, A., Briner, J. P., Brouard, E., Campbell, J. E., Carlson, A. E., Clague, J. J., Curry, B. B., Daigneault, R.-A., Dubé-Loubert, H., Easterbrook, D. J., Franzi, D. A., Friedrich, H. G., Funder, S., Gauthier, M. S., Gowan, A. S., Harris, K. L., Hétu, B., Hooyer, T. S., Jennings, C. E., Johnson, M. D., Kehew, A. E., Kelley, S. E., Kerr, D., King, E. L., Kjeldsen, K. K., Knaeble, A. R., Lajeunesse, P., Lakeman, 345 T. R., Lamothe, M., Larson, P., Lavoie, M., Loope, H. M., Lowell, T. V., Lusardi, B. A., Manz, L., McMartin, I., Nixon, F. C., Occhietti, S., Parkhill, M. A., Piper, D .J. W., Pronk, A. G., Richard, P. J. H., Ridge, J. C., Ross, M., Roy, M., Seaman, A., Shaw, J., Stea, R. R., Teller, J. T., Thompson, W. B., Thorleifson, L. H., Utting, D. J., Veillette, J. J., Ward, B. C., Weddle, T. 
https://doi.org/10.5194/bg-2021-4

Preprint. Discussion started: 21 January 2021

(c) Author(s) 2021. CC BY 4.0 License.

(c) (i)

K. and Wright, H. E.: An updated radiocarbon-based ice margin chronology for the last deglaciation of the North American Ice Sheet Complex. Quat. Sci. Rev., 234, 106223, 2020.

350 Dinauer, A., Adolphi, F. and Joos, F.: Mysteriously high $\Delta{ }^{14} \mathrm{C}$ of the glacial atmosphere: influence of ${ }^{14} \mathrm{C}$ production and carbon cycle changes. Clim. Past, 16, 1159-1185, 2020.

Dyke, A. S.: An outline of North American deglaciation with emphasis on central and northern Canada, in: Ehlers, J., Gibbard, P. L. Developments in Quaternary Sciences. Elsevier, pp. 373-424, 2004.

Fischer, C. and Gaupp, R.: Change of black shale organic material surface area during oxidative weathering: Implications for rock-water surface evolution, Geochim. Cosmochim. Acta, 69, 1213-1224, 2005.

Fischer, C., Karius, V. and Thiel, V.: Organic matter in black slate shows oxidative degradation within only a few decades, J. Sediment. Res., 77, 355-365, 2007.

Galy V., Beyssac O., France-Lanord C. and Eglinton T. I.: Recycling of graphite during Himalayan erosion: A geological stabilization of carbon in the crust. Science, 322, 943-945, 2008.

360 Galy V., Peucker-Ehrenbrink B. and Eglinton T. I.: Global carbon export from the terrestrial biosphere controlled by erosion. Nature, 521, 204-207, 2015.

Georg R. B., West A. J., Vance D., Newman K. and Halliday A. N.: Is the marine osmium isotope record a probe for $\mathrm{CO}_{2}$ release from sedimentary rocks? Earth Planet. Sci. Lett., 367, 28-38, 2013.

Hain, M. P., Sigman, D. M. and Haug, G. H.: Distinct roles of the Southern Ocean and North Atlantic in the deglacial atmospheric radiocarbon decline. Earth Planet. Sci. Lett., 394, 198-208, 2014.

Harden, J. W., Mark, R. K., Sundquist, E. T. and Stallard, R. F.: Dynamics of soil carbon during deglaciation of the Laurentide Ice Sheet, Science, 258, 1921, 1992.

Hays J. D., Imbrie J. and Shackleton N. J.: Variations in the Earth's orbit: Pacemaker of the Ice Ages. Science, 194, 11211132, 1976.

370 Hedges J. I. and Oades J. M.: Comparative organic geochemistries of soils and marine sediments. Org. Geochem., 27, 319$361,1997$.

Herman F., Seward D., Valla P. G., Carter A., Kohn B., Willett S. D. and Ehlers T. A.: Worldwide acceleration of mountain erosion under a cooling climate. Nature, 504, 423-426, 2013.

Herman F., Beyssac O., Brughelli M., Lane S. N., Leprince S., Adatte T., Lin J. Y. Y., Avouac J.-P. and Cox S. C.: Erosion 375 by an Alpine glacier. Science, 350, 193-195, 2015.

Hemingway J. D., Hilton R. G., Hovius N., Eglinton T. I., Haghipour N., Wacker L., Chen M.-C. and Galy V. V.: Microbial oxidation of lithospheric organic carbon in rapidly eroding tropical mountain soils. Science, 360, 209, 2018.

Hilton R. G., Gaillardet J., Calmels D. and Birck J.-L.: Geological respiration of a mountain belt revealed by the trace element rhenium. Earth Planet. Sci. Lett., 403, 27-36, 2014.

380 Hood E., Fellman J., Spencer R. G. M., Hernes P. J., Edwards R., D’Amore D. and Scott D.: Glaciers as a source of ancient and labile organic matter to the marine environment. Nature, 462, 1044, 2009. 
https://doi.org/10.5194/bg-2021-4

Preprint. Discussion started: 21 January 2021

(c) Author(s) 2021. CC BY 4.0 License.

\section{(c) (1)}

Horan K., Hilton R. G., Dellinger M., Tipper E., Galy V., Calmels D., Selby D., Gaillardet J., Ottley C. J., Parsons D. R. and Burton K. W. Carbon dioxide emissions by rock organic carbon oxidation and the net geochemical carbon budget of the Mackenzie River Basin. Am. J. Sci., 319, 473-499, 2019.

Horan K., Hilton R. G., Selby D., Ottley C. J., Gröcke D. R., Hicks M. and Burton K. W.: Mountain glaciation drives rapid oxidation of rock-bound organic carbon. Sci. Adv., 3, 2017.

Horan K.: The oxidative weathering of organic matter and its carbon dioxide emissions: Insight from the trace elements rhenium and molybdenum, Ph.D. thesis, Durham University, United Kingdom, 223 pp., 2018.

Köhler, P., Knorr, G. and Bard, E.: Permafrost thawing as a possible source of abrupt carbon release at the onset of the Bølling/Allerød. Nat. Commun. 5, 5520, 2014.

Kump L. R., Junium C., Arthur M. A., Brasier A., Fallick A., Melezhik V., Lepland A., Črne A. E. and Luo G.: Isotopic evidence for massive oxidation of organic matter following the Great Oxidation Event. Science, 334, 1694-1696, 2011.

Lin, B., Liu, Z., Eglinton, T. I., Kandasamy, S., Blattmann, T. M., Haghipour, N., Huang, K.-F. and You, C.-F.: Island-wide variation in provenance of riverine sedimentary organic carbon: A case study from Taiwan, Earth Planet. Sci. Lett., 539, $116238,2020$.

Littke, R., Klussmann, U., Krooss, B. and Leythaeuser, D.: Quantification of loss of calcite, pyrite, and organic matter due to weathering of Toarcian black shales and effects on kerogen and bitumen characteristics, Geochim. Cosmochim. Acta, 55, 3369-3378, 1991.

Lyons S. L., Baczynski A. A., Babila T. L., Bralower T. J., Hajek E. A., Kump L. R., Polites E. G., Self-Trail J. M., Trampush

400 S. M., Vornlocher J. R., Zachos J. C. and Freeman K. H.: Palaeocene-Eocene Thermal Maximum prolonged by fossil carbon oxidation. Nat. Geosci., 12, 54-60, 2019.

Marcott, S. A., Bauska, T. K., Buizert, C., Steig, E. J., Rosen, J. L., Cuffey, K. M., Fudge, T. J., Severinghaus, J. P., Ahn, J., Kalk, M. L., McConnell, J. R., Sowers, T., Taylor, K. C., White, J. W. C. and Brook, E. J.: Centennial-scale changes in the global carbon cycle during the last deglaciation, Nature, 514, 2014.

405 Martin, J. H.: Glacial-interglacial $\mathrm{CO}_{2}$ change: The iron hypothesis, Paleoceanography, 5, 1-13, 1990.

Menviel, L., Spence, P., Yu, J., Chamberlain, M. A., Matear, R. J., Meissner, K. J. and England, M. H.: Southern Hemisphere westerlies as a driver of the early deglacial atmospheric $\mathrm{CO}_{2}$ rise, Nat. Commun., 9, 2503, 2018.

Miall, A. D. and Blakey, R. C.: The Phanerozoic tectonic and sedimentary evolution of North America, in: The Sedimentary Basins of the United States and Canada (Second Edition), edited by: Miall, A. D., Elsevier, 1-38, 2019.

Moran J. E., Fehn U. and Teng R. T. D.: Variations in ${ }^{129} \mathrm{I} /{ }^{127} \mathrm{I}$ ratios in recent marine sediments: evidence for a fossil organic component. Chem. Geol., 152, 193-203, 1998.

Petsch S. T., Eglinton T. I. and Edwards K. J.: ${ }^{14} \mathrm{C}$-dead living biomass: Evidence for microbial assimilation of ancient organic carbon during shale weathering. Science, 292, 1127-1131, 2001.

Petsch S. T.: Weathering of organic carbon, in: Holland H.D., Turekian K.K., Treatise on Geochemistry. Elsevier, Oxford, pp. $415 \quad 217-238,2014$. 
https://doi.org/10.5194/bg-2021-4

Preprint. Discussion started: 21 January 2021

(c) Author(s) 2021. CC BY 4.0 License.

\section{(c) (1)}

Peucker-Ehrenbrink, B. and Ravizza, G. E.: Osmium isotope stratigraphy, in: Geologic Time Scale 2020, edited by: Gradstein, F. M., Ogg, J. G., Schmitz, M. D., and Ogg, G. M., Elsevier, 239-257, 2020.

Rafter, P. A., Carriquiry, J. D., Herguera, J.-C., Hain, M. P., Solomon, E. A. and Southon, J. R.: Anomalous > 2000-year-old surface ocean radiocarbon age as evidence for deglacial geologic carbon release. Geophys. Res. Lett., 46, 13950-13960, 2019.

Rapp, D.: Ice Ages and Interglacials: Measurements, Interpretation, and Models. $3^{\text {rd }}$ edition, Springer Nature Switzerland, pp. 346, 2019.

Ravizza G. and Esser B. K.: A possible link between the seawater osmium isotope record and weathering of ancient sedimentary organic matter. Chem. Geol., 107, 255-258, 1993.

Reimer P. J., Bard E., Bayliss A., Beck J. W., Blackwell P. G., Ramsey C. B., Buck C. E., Cheng H., Edwards R. L., Friedrich M., Grootes P. M., Guilderson T. P., Haflidason H., Hajdas I., Hatté C., Heaton T. J., Hoffmann D. L., Hogg A. G., Hughen K. A., Kaiser K. F., Kromer B., Manning S. W., Niu M., Reimer R. W., Richards D. A., Scott E. M., Southon J. R., Staff R. A., Turney C. S. M. and van der Plicht J.: IntCal13 and Marine13 radiocarbon age calibration curves 0-50,000 years cal BP. Radiocarbon, 55, 1869-1887, 2013.

Roffey, R. and Norqvist, A.: Biodegradation of bitumen used for nuclear waste disposal, Experientia, 47, 539-542, 1991.

430 Rogieri Pelissari, M., Oliveira Sawakuchi, H., Bertassoli Junior, D. J., da Silva Almeida, N. and Oliveira Sawakuchi, A.: Water influence on $\mathrm{CH}_{4}$ and $\mathrm{CO}_{2}$ generation from tar sandstones: Insights from incubation experiments in the Pirambóia Formation, Paraná Basin, J. S. Am. Earth Sci., 106, 103097, 2021.

Roth R. and Joos F.: Model limits on the role of volcanic carbon emissions in regulating glacial-interglacial $\mathrm{CO}_{2}$ variations. Earth Planet. Sci. Lett., 329-330, 141-149, 2012.

435 Roth R. and Joos F.: A reconstruction of radiocarbon production and total solar irradiance from the Holocene ${ }^{14} \mathrm{C}_{\text {and }} \mathrm{CO}_{2}$ records: implications of data and model uncertainties. Clim. Past, 9, 1879-1909, 2013.

Roy, M., Clark, P. U., Raisbeck, G. M. and Yiou, F.: Geochemical constraints on the regolith hypothesis for the middle Pleistocene transition, Earth Planet. Sci. Lett., 227, 281-296, 2004.

Rutherford R. L.; Two interesting boulders in the glacial deposits of Alberta. J. Geol., 36, 558-563, 1928.

440 Sarnthein, M., Schneider, B. and Grootes, P. M.: Peak glacial ${ }^{14} \mathrm{C}$ ventilation ages suggest major draw-down of carbon into the abyssal ocean, Clim. Past, 9, 2595-2614, 2013.

Sauramo M. R.: The mode of occurrence of carbon in Quaternary deposits. Suomen Kemistilehti, 3, 11-16, 1938.

Schillawski S. and Petsch S.: Release of biodegradable dissolved organic matter from ancient sedimentary rocks. Global Biogeochem. Cycles, 22, 2008.

445 Schmitt J., Schneider R., Elsig J., Leuenberger D., Lourantou A., Chappellaz J., Köhler P., Joos F., Stocker T. F., Leuenberger M. and Fischer H.: Carbon isotope constraints on the deglacial $\mathrm{CO}_{2}$ rise from ice cores. Science, 336, 711-714, 2012.

Shackleton N. J.: Carbon-13 in Uvigerina: Tropical rainforest history and the equatorial Pacific carbonate dissolution cycles, in: Andersen N. R. and Malahoff A. The Fate of Fossil Fuel $\mathrm{CO}_{2}$ in the Oceans. Plenum Press, pp. 401-427, 1997. 
https://doi.org/10.5194/bg-2021-4

Preprint. Discussion started: 21 January 2021

(c) Author(s) 2021. CC BY 4.0 License.

(c) (i)

Shackleton N. J., Hall M. A., Line J. and Shuxi C.: Carbon isotope data in core V19-30 confirm reduced carbon dioxide concentration in the ice age atmosphere. Nature 306, 319-322, 1983.

Sharp M., Parkes J., Cragg B., Fairchild I. J., Lamb H. and Tranter M.: Widespread bacterial populations at glacier beds and their relationship to rock weathering and carbon cycling. Geology 27, 107-110, 1999.

Sharp, M. and Tranter, M.: Glacier biogeochemistry, Geochem. Perspect., 6, 173-174, 2017.

Sigman D. M., Hain M. P. and Haug G. H.: The polar ocean and glacial cycles in atmospheric $\mathrm{CO}_{2}$ concentration. Nature 466, $455 \quad 47-55,2010$.

Sigman D. M. and Boyle E. A.: Glacial/interglacial variations in atmospheric carbon dioxide. Nature, 407, 859-869, 2000.

Simmons, C. T., Matthews, H. D. and Mysak, L. A.: Deglacial climate, carbon cycle and ocean chemistry changes in response to a terrestrial carbon release. Clim. Dyn., 46, 1287-1299, 2016.

Smith H. J., Fischer H., Wahlen M., Mastroianni D. and Deck B.: Dual modes of the carbon cycle since the Last Glacial

Maximum. Nature, 400, 248-250, 1999.

Sparkes, R. B., Hovius, N., Galy, A. and Liu, J. T.: Survival of graphitized petrogenic organic carbon through multiple erosional cycles, Earth Planet. Sci. Lett., 531, 115992, 2020.

Steffen W., Rockström J., Richardson K., Lenton T. M., Folke C., Liverman D., Summerhayes C. P., Barnosky A. D., Cornell S. E., Crucifix M., Donges J. F., Fetzer I., Lade S. J., Scheffer M., Winkelmann R. and Schellnhuber H. J.: Trajectories of the 465 Earth system in the Anthropocene. Proc. Natl. Acad. Sci. U.S.A., 115, 8252, 2018.

Stips A., Macias D., Coughlan C., Garcia-Gorriz E. and Liang X. S.: On the causal structure between $\mathrm{CO}_{2}$ and global temperature. Sci. Rep., 6, 21691, 2016.

Stolper D. A., Bender M. L., Dreyfus G. B., Yan Y. and Higgins J. A.: A Pleistocene ice core record of atmospheric $\mathrm{O}_{2}$ concentrations. Science, 353, 1427-1430, 2016.

470 Stroeven, A. P., Hättestrand, C., Kleman, J., Heyman, J., Fabel, D., Fredin, O., Goodfellow, B. W., Harbor, J. M., Jansen, J. D., Olsen, L., Caffee, M. W., Fink, D., Lundqvist, J., Rosqvist, G. C., Strömberg, B. and Jansson, K. N.: Deglaciation of Fennoscandia. Quat. Sci. Rev., 147, 91-121, 2016.

Tesi T., Muschitiello F., Smittenberg R. H., Jakobsson M., Vonk J. E., Hill P., Andersson A., Kirchner N., Noormets R., Dudarev O., Semiletov I. and Gustafsson Ö.: Massive remobilization of permafrost carbon during post-glacial warming. Nat.

475 Commun. 7, 13653, 2016.

Torres M. A., West A. J. and Li G.: Sulphide oxidation and carbonate dissolution as a source of $\mathrm{CO}_{2}$ over geological timescales. Nature, 507, 346-349, 2014.

Torres M. A., Moosdorf N., Hartmann J., Adkins J. F. and West A. J.: Glacial weathering, sulfide oxidation, and global carbon cycle feedbacks. Proc. Natl. Acad. Sci. U.S.A., 1-6, 2017.

480 Vance D., Teagle D. A. H. and Foster G. L.: Variable Quaternary chemical weathering fluxes and imbalances in marine geochemical budgets. Nature, 458, 493-496, 2009. 
https://doi.org/10.5194/bg-2021-4

Preprint. Discussion started: 21 January 2021

(c) Author(s) 2021. CC BY 4.0 License.

(c) (1)

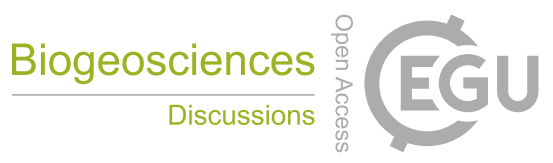

Winterfeld, M., Mollenhauer, G., Dummann, W., Köhler, P., Lembke-Jene, L., Meyer, V. D., Hefter, J., McIntyre, C., Wacker,

L., Kokfelt, U. and Tiedemann, R.: Deglacial mobilization of pre-aged terrestrial carbon from degrading permafrost. Nat. Commun., 9, 3666, 2018.

485 Wong, M.-L., An, D., Caffrey, S. M., Soh, J., Dong, X., Sensen, C. W., Oldenburg, T. B. P., Larter, S. R. and Voordouw, G.: Roles of thermophiles and fungi in bitumen degradation in mostly cold oil sands outcrops, Appl. Environ. Microbiol., 81, 6825, 2015.

Wyndham, R. C. and Costerton, J. W.: In vitro microbial degradation of bituminous hydrocarbons and in situ colonization of bitumen surfaces within the Athabasca oil sands deposit, Appl. Environ. Microbiol., 41, 791, 1981.

490 Uribe-Alvarez, C., Ayala, M., Perezgasga, L., Naranjo, L., Urbina, H. and Vazquez-Duhalt, R.: First evidence of mineralization of petroleum asphaltenes by a strain of Neosartorya fischeri, Microb. Biotechnol., 4, 663-672, 2011.

Zeng N.: Glacial-interglacial atmospheric $\mathrm{CO}_{2}$ change - The glacial burial hypothesis. Adv. Atmospheric Sci., 20, 677-693, 2003.

Zeng N.: Quasi-100 ky glacial-interglacial cycles triggered by subglacial burial carbon release. Clim. Past., 3, 135-153, 2007.

495 Zhao N., Marchal O., Keigwin L., Amrhein D. and Gebbie G.: A synthesis of deglacial deep-sea radiocarbon records and their (in)consistency with modern ocean ventilation. Paleoceanogr. Paleocl., 33, 128-151, 2018.

ZoBell, C. E.: Action of microörganisms on hydrocarbons, Bacteriol. Rev., 10, 1-49, 1946. 
https://doi.org/10.5194/bg-2021-4

Preprint. Discussion started: 21 January 2021

(c) Author(s) 2021. CC BY 4.0 License.

Table 1: Fluxes of kerogen oxidation normalized to one year from onsite (soil and outcrops), catchment-wide studies (river), and laboratory-based incubation studies ordered approximately from small to large $\mathrm{CO}_{2}$ release fluxes.

\begin{tabular}{|c|c|c|c|}
\hline Area/ Material & $\begin{array}{l}\text { Oxidation flux } \\
{\left[\mathrm{MgC} / \mathrm{km}^{2} / \mathrm{yr}\right]}\end{array}$ & Comments & References \\
\hline \multirow[t]{2}{*}{ Andes } & $\geq 0.3$ & $\begin{array}{l}\text { Kerogen oxidation in the Madeira floodplain based on } \\
\text { radiocarbon isotope mass balancing of sedimentary organic } \\
\text { carbon. Oxidation flux normalized to catchment area reported } \\
\text { in Clark et al., (2017). }\end{array}$ & $\begin{array}{l}\text { Bouchez et al., } \\
(2010)\end{array}$ \\
\hline & $\sim 1.2$ & $\begin{array}{l}\text { Kerogen oxidation in the Madeira floodplain based on } \\
\text { radiocarbon isotope mass balancing of sedimentary organic } \\
\text { carbon refining the result by Bouchez et al. (2010). }\end{array}$ & Clark et al., (2017) \\
\hline $\begin{array}{l}\text { Mackenzie } \\
\text { River Basin }\end{array}$ & $0.45_{-0.11}^{+0.19}$ & $\begin{array}{l}\text { Rhenium-based estimate integrating over catchment and } \\
\text { riverine in-situ weathering. }\end{array}$ & Horan et al., (2019) \\
\hline Global average & $0.72_{-0.41}^{+0.17}$ & $\begin{array}{l}\text { Calculated global average rate of kerogen oxidation on land. } \\
\text { See Equation } 1 .\end{array}$ & See text. \\
\hline $\begin{array}{l}\text { Soil, glacial till } \\
\text { (Canada) }\end{array}$ & 4.2 & $\begin{array}{l}\text { Holocene-averaged flux of onsite kerogen oxidation based on } \\
\mathrm{CO}_{2} \text { evolution and carbon isotopes. }\end{array}$ & $\begin{array}{l}\text { Keller and Bacon } \\
(1998)\end{array}$ \\
\hline \multirow{3}{*}{ Taiwan } & $6.1-18.6$ & $\begin{array}{l}\text { Radiocarbon biogeochemistry reveals microbially-mediated } \\
\text { weathering of kerogen onsite in soils. }\end{array}$ & $\begin{array}{l}\text { Hemingway et al., } \\
(2018)\end{array}$ \\
\hline & $12 \pm 6$ & $\begin{array}{l}\text { Sedimentary organic carbon mass balancing with radiocarbon } \\
\text { integrating over catchment and riverine in-situ weathering }\end{array}$ & Hilton et al., (2011) \\
\hline & $7-13$ & $\begin{array}{l}\text { Rhenium-based estimate integrating over catchment and } \\
\text { riverine in-situ weathering. }\end{array}$ & Hilton et al., (2014) \\
\hline $\begin{array}{l}\text { Shale } \\
\text { (Posidonia, } \\
\text { Germany) }\end{array}$ & $11-16$ & $\begin{array}{l}\text { Onsite kerogen oxidation based on Holocene scenario } \\
\text { described in reference using mass loss of kerogen and } \\
\text { estimated erosion rates. Weathering depth of } 5 \mathrm{~m} \text { and organic } \\
\text { carbon to organic matter conversion factor of } 1.5 \text { assumed. }\end{array}$ & Littke et al., (1991) \\
\hline $\begin{array}{l}\text { Southern Alps, } \\
\text { New Zealand }\end{array}$ & $9-50$ & $\begin{array}{l}\text { Rhenium-based estimate integrating over catchment and } \\
\text { riverine in-situ weathering. Oxidation fluxes reported for } 4 \\
\text { catchments with minimum and maximum reported here. }\end{array}$ & Horan et al., (2017) \\
\hline $\begin{array}{l}\text { Tar sandstone } \\
\text { (Brazil) }\end{array}$ & $\sim 54$ & $\begin{array}{l}\text { Laboratory-based experiments over } 1 \text { year duration under } \\
\text { water saturated and anoxic conditions at } 20^{\circ} \mathrm{C} \text {. Results scaled } \\
\text { with density taken as } 2000 \mathrm{~kg} / \mathrm{m}^{3} \text { and } 1 \mathrm{~m} \text { weathering depth. }\end{array}$ & $\begin{array}{l}\text { Rogieri Pelissari et } \\
\text { al., (2021) }\end{array}$ \\
\hline $\begin{array}{l}\text { Shale (Jurassic } \\
\text { marl, France) }\end{array}$ & $61-64$ & $\begin{array}{l}\text { Field-based observations spanning over minutes to up to } 101 \\
\text { days using zeolite traps. }\end{array}$ & Soulet et al., (2018) \\
\hline $\begin{array}{l}\text { Bituminous } \\
\text { coal }\end{array}$ & $320-530$ & $\begin{array}{l}\text { Laboratory-based subaquatic oxidation experiments at } 24^{\circ} \mathrm{C} \\
\text { for air-saturated water over } 179-442 \text { days duration. Carbon } \\
\text { release calculated assuming } 30-50 \% \text { of oxygen reacts to form } \\
\mathrm{CO}_{2} \text {, an average specific surface area of coal of } 1 \mathrm{~m}^{2} / \mathrm{g} \text {, } \\
\text { average density of } 1400 \mathrm{~kg} / \mathrm{m}^{3} \text {, and } 1 \mathrm{~m} \text { weathering depth. }\end{array}$ & $\begin{array}{l}\text { Chang and Berner } \\
(1998,1999)\end{array}$ \\
\hline Shale (Brazil) & $80-1050$ & $\begin{array}{l}\text { Laboratory-based experiments over } 75 \text { days duration under } \\
\text { water saturated, dark, and anoxic conditions at } 25^{\circ} \mathrm{C} \text {. Results } \\
\text { scaled with density taken as } 2200 \mathrm{~kg} / \mathrm{m}^{3} \text { and } 1 \mathrm{~m} \text { weathering } \\
\text { depth. }\end{array}$ & $\begin{array}{l}\text { Bertassoli Jr. et al., } \\
\text { (2016) }\end{array}$ \\
\hline $\begin{array}{l}\text { Oil sands } \\
\text { (Bitumen) }\end{array}$ & $6800-13000$ & $\begin{array}{l}\text { Laboratory-based experiments of } 100 \text { days duration for } \\
\text { biodegradation of bitumen with different microbial cultures. } \\
\text { Results scaled to oil sands with density taken as } 2000 \mathrm{~kg} / \mathrm{m}^{3} \\
\text { with } 10 \% \text { bitumen content, and } 1 \mathrm{~m} \text { weathering depth. }\end{array}$ & $\begin{array}{l}\text { Ait-Langomazino et } \\
\text { al., (1991) }\end{array}$ \\
\hline
\end{tabular}




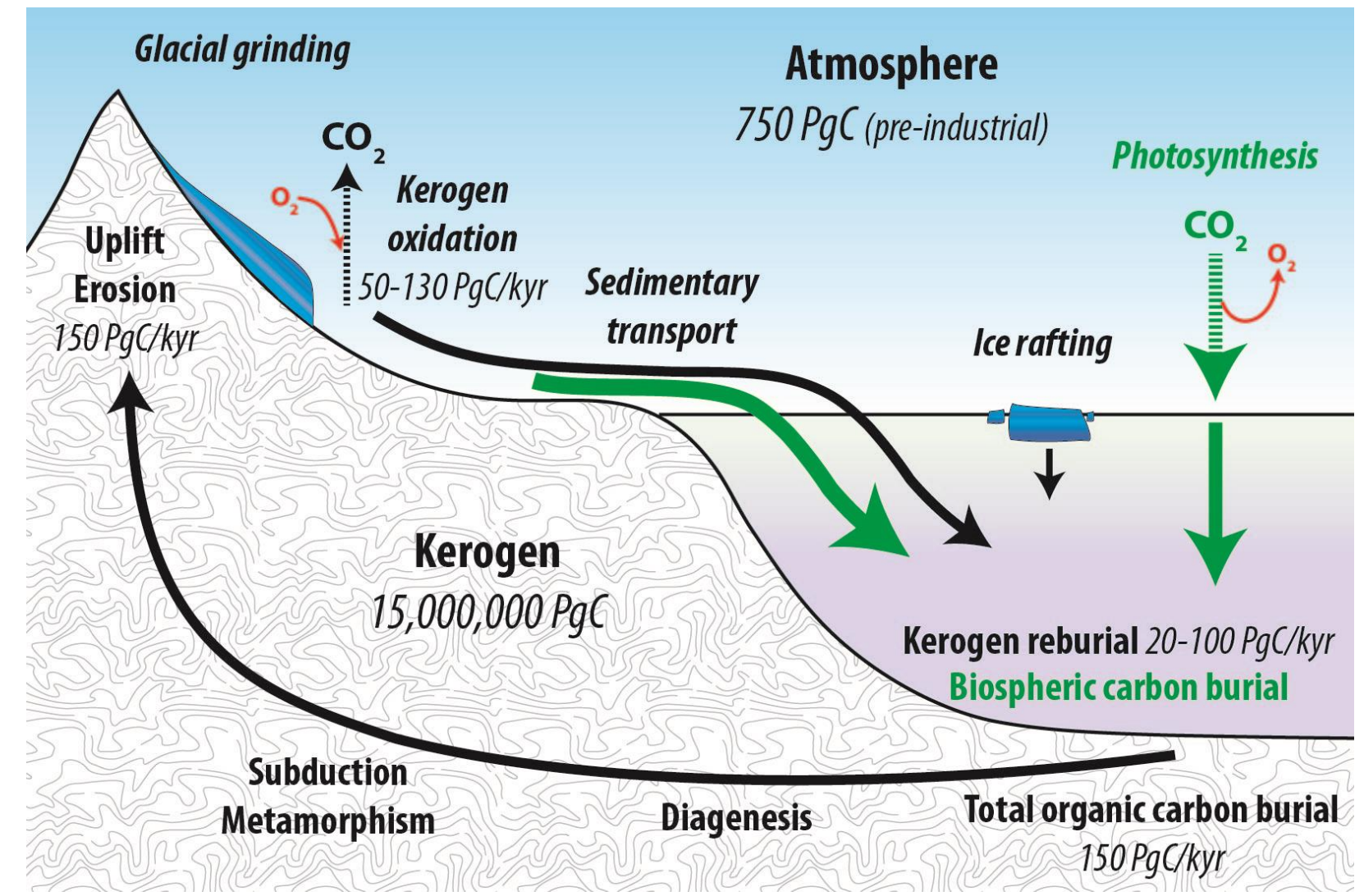

Figure 1: Organic carbon cycle with the flow of kerogen (black solid lines) and the flow of biospheric carbon (green solid lines) showing both the fixation of atmospheric $\mathrm{CO}_{2}$ by terrestrial and marine primary productivity. The combined flux of reworked kerogen and biospheric carbon into ocean sediments constitutes total organic carbon burial entering the endogenous kerogen pool (Galy et al., 2015; Hedges and Oades, 1997). 


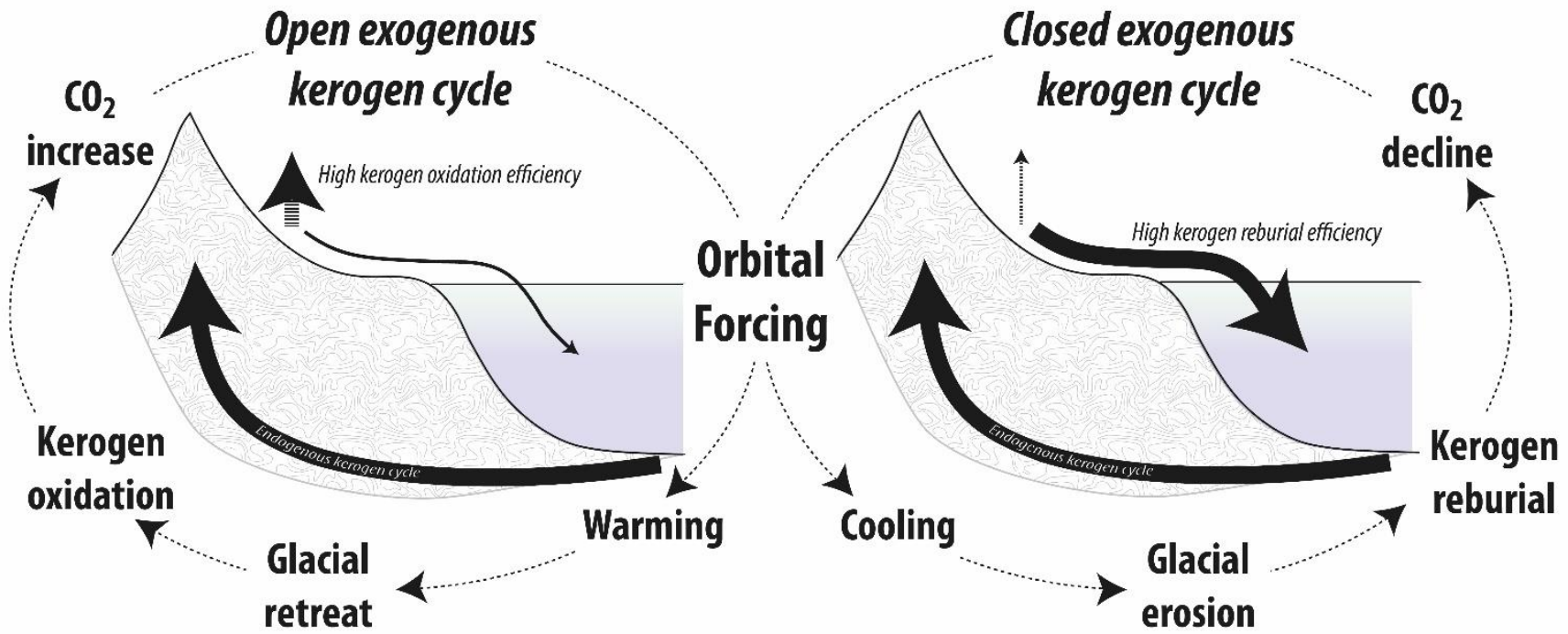

Figure 2: Conceptual hypothesis overview: Changes in kerogen reburial efficiency and its effect on the reentry of ancient carbon into surficial carbon pools as a function of overall climate state. During glacial times, kerogen reburial is promoted by the activity of glaciers and ice sheets with relatively little oxidation of this carbon during its transit across Earth's surface characteristic of a "closed" exogenous kerogen cycle. During glacial terminations and interglacials, the oxidation of kerogen is more efficient leading to the exhalation of this carbon to the atmosphere characteristic of an "open" exogenous kerogen cycle. 
https://doi.org/10.5194/bg-2021-4

Preprint. Discussion started: 21 January 2021

(c) Author(s) 2021. CC BY 4.0 License.

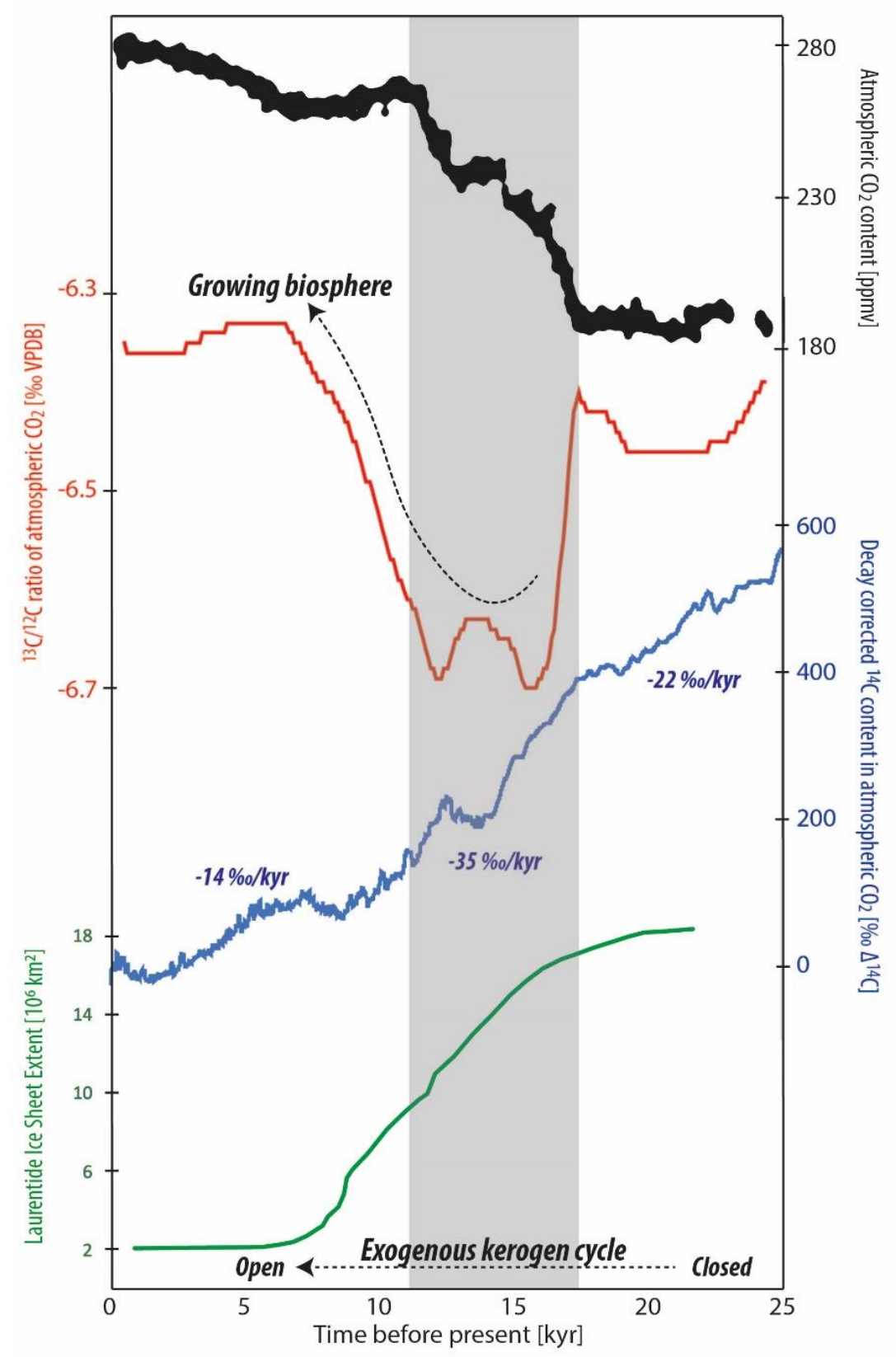

Figure 3: Evolution of atmospheric $\mathrm{CO}_{2}$ and its carbon isotopic composition starting from the Last Glacial Maximum with redrawn data from Schmitt et al. (2012) and ${ }^{14} \mathrm{C}$ data from Reimer et al. (2013). The area of the Laurentide Ice Sheet (including Greenland) is plotted after Dalton et al. (2020). The gray time envelope indicates the greatest rate of atmospheric $\mathrm{CO}_{2}$ increase coinciding with a pronounced negative pulse in stable carbon isotopic composition and accelerated decrease in radiocarbon concentration. In addition to the hypothesized role of kerogen oxidation, the superimposed effects of ocean-air gas exchange, an increasingly voluminous terrestrial biosphere, changes in radiocarbon production in the atmosphere, etc. all contribute to the evolution of these parameters. 
https://doi.org/10.5194/bg-2021-4

Preprint. Discussion started: 21 January 2021

(c) Author(s) 2021. CC BY 4.0 License.

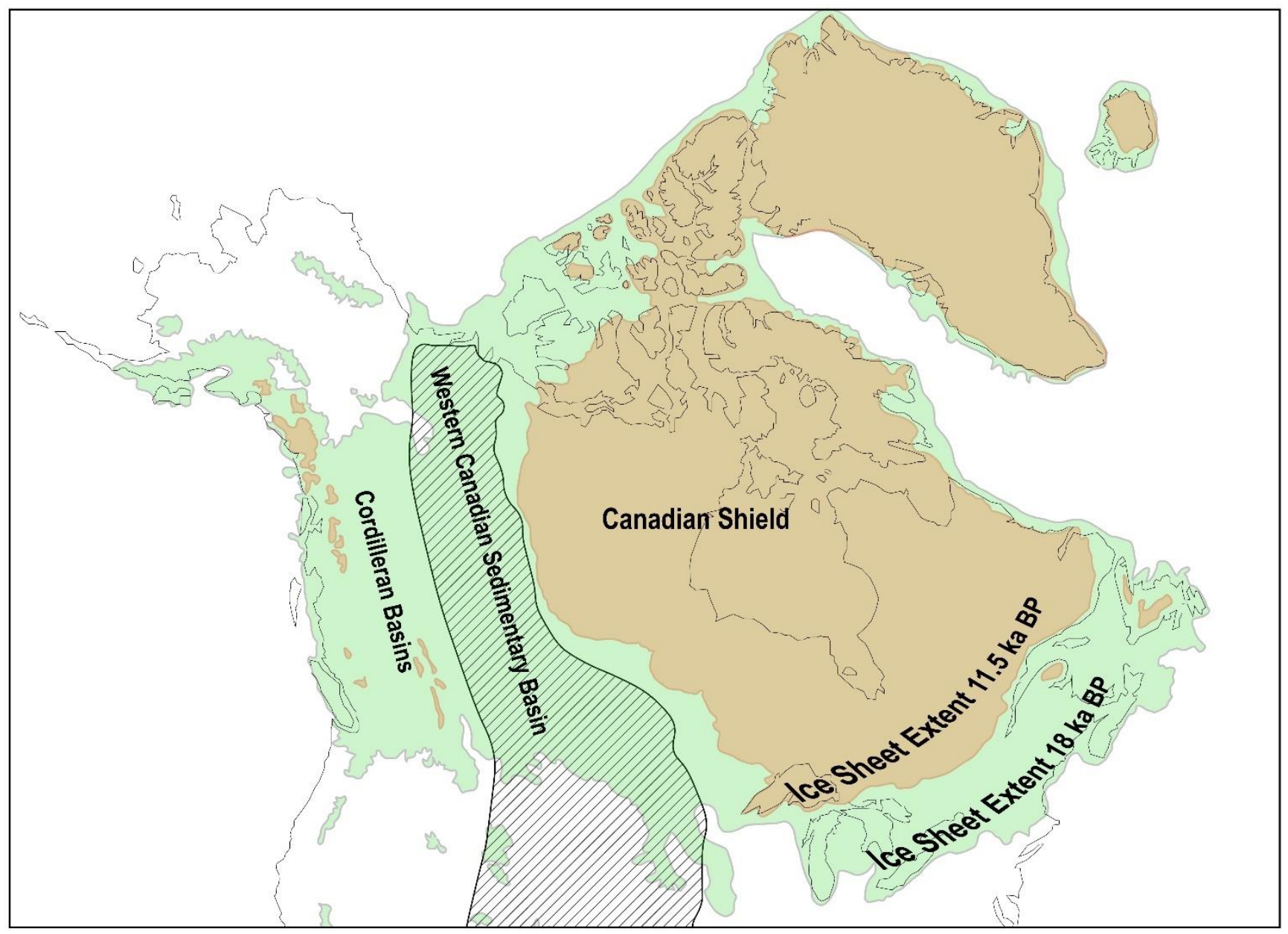

525 Figure 4: Laurentide Ice sheet extents bracketing the time span of most pronounced glacial-interglacial $\mathrm{CO}_{2}$ increase (redrawn after Dalton et al., 2020). Sedimentary basins showing the Western Canadian Sedimentary Basin (hatched area, with extension of related units into the United States) and the Cordilleran Basins and Canadian Shield to the east and west, respectively (simplified after Miall and Blakey, 2019). The surficial kerogen content in the Canadian Shield is generally low, while high kerogen contents are present along the axes of the Cordilleran and Western Canadian Sedimentary Basins (see Fig. 2 in Copard et al., 2007). $\leq 300$ years after glacial retreat extended into the Canadian Shield, the rise in atmospheric $\mathrm{CO}_{2}$ subsided (compare with Fig. 3). Here, kerogen oxidation mainly in western Canada is hypothesized to have acted as a major source of $\mathrm{CO}_{2}$ to the atmosphere in the wake of glacial retreat. 